\title{
System of Measuring PH, Humidity, and Temperature Based on Internet of Things (IoT)
}

\section{Sistem Pengukuran PH, Kelembapan, dan Suhu Berbasis Internet of Things (IoT)}

\author{
Wahyuni Eka Sari ${ }^{1}$, Eko Junirianto ${ }^{2}$, Geofani Fatur Rahman ${ }^{3}$ \\ ${ }^{1}$ Teknologi Rekayasa Komputer, Politeknik Negeri Samarinda, Samarinda, Indonesia \\ 1,2,3 Teknologi Rekayasa Perangkat Lunak, Politeknik Pertanian Negeri Samarinda, Samarinda, Indonesia
}

\section{INFORMASI ARTIKEL}

\section{Riwayat Artikel:}

Dikirimkan 11 Desember 2020,

Direvisi 01 Januari 2021,

Diterima 29 Januari 2021.

\section{Kata Kunci:}

Cabai;

Arduino Uno;

Antares;

pH tanah;

Kelembapan Tanah;

Suhu Udara;

Internet of Things (IOT)

\section{Penulis Korespondensi:}

Geofani Fatur Perdana,

Teknologi Rekayasa Perangkat

Lunak, Politeknik Pertanian

Negeri Samarinda,

J1. Cipto Mangun Kusumo,

Sungai Keledang, Samarinda

Seberang, Samarinda,

Indonesia.

geofanifatur@gmail.com

\begin{abstract}
The problem faced by farmers in Samarinda is the difficulties to know the condition of the chili plants when they are away from home or from the garden. Often times the farmer commutes from home to the garden just to monitor the condition of the plants, which reduces work effectiveness and takes a long time. Therefore, in this study a tool was made to measure soil moisture, temperature and soil $\mathrm{pH}$ based on the Internet of Things. The process of monitoring soil $\mathrm{pH}$, soil moisture, and air temperature in chili plants using soil pH sensors, soil moisture sensors, and soil temperature sensors as well as Wemos / Arduino for data processing and sending analog data to the ANTARES platform. The result of this research is that soil condition data can be sent and read in real time through the ANTARES web application. Tool testing was carried out at 30 different locations in the city of Samarinda.
\end{abstract}

Permasalahan yang dihadapi oleh petani cabai di Samarinda adalah kesulitan untuk mengetahui keadaan tanaman ketika sedang berada jauh dari rumah atau dari kebun. Sering kali petani pulang pergi dari rumah ke kebun hanya untuk memantau keadaan tanaman sehingga mengurangi efektivitas kerja dan membutuhkan waktu yang lama. Oleh sebab itu pada penelitian ini dibuat alat untuk mengukur Kelembapan tanah, suhu dan $\mathrm{pH}$ tanah berbasis Internet of Things. Proses monitoring $\mathrm{pH}$ tanah, kelembapan tanah, dan suhu udara pada tanaman cabai menggunakan sensor $\mathrm{pH}$ tanah, sensor soil moisture, dan sensor suhu tanah serta Wemos/Arduino untuk pengolahan data dan pengiriman data analog ke platfrom ANTARES. Hasil dari penelitian ini adalah data kondisi tanah dapat terkirim dan terbaca secara realtime melalui aplikasi web ANTARES. Pengujian alat dilakukan pada 30 lokasi berbeda di kota Samarinda.

This work is licensed under a Creative Commons Attribution-Share Alike 4.0

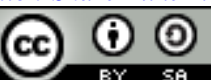

\section{Sitasi Dokumen ini:}

W. E. Sari, E. Junirianto, and G. F. Rahman, "System of Measuring PH, Humidity, and Temperature Based on Internet of Things (IoT)," Buletin Ilmiah Sarjana Teknik Elektro, vol. 1, no. 3, pp. 72-81, 2021. DOI: 10.12928/biste.v3i1.3214 


\section{PENDAHULUAN}

Cabai termasuk tanaman hortikultura yang banyak dibudidayakan oleh masyarakat dan petani di Samarinda. Saat ini para petani telah mampu membudidayakan cabai dengan kualitas lebih baik serta mampu menghasilkan produk yang optimal karena telah mampu mengatasi berbagai macam teknik penanaman, perawatan, pemberian pupuk, sistem pengairan dan pengendalian hama. Namun, petani kesulitan memonitoring kondisi tanah untuk tanaman cabai. Lahan yang luas dan kondisi iklim di Samarinda yang berubahubah menyebabkan tanaman cabai mudah busuk dan menghasilkan panen yang tidak melimpah. Petani perlu menjaga unsur-unsur hara di dalam tanah. Banyak sedikitnya kandungan unsur hara pada tanah merupakan indikator tingkat kesuburan tanah yang akan mempengaruhi proses pertumbuhan dan perkembangan tanaman. Tingkat kesuburan tanah dipengaruhi oleh beberapa faktor yaitu derajat keasaman tanah $\mathrm{pH}$ tanah, suhu, dan kelembapan tanah. Sehingga pada penelitian ini dibangun alat pengukuran $\mathrm{pH}$ tanah, kelembaban tanah, dan suhu udara berbasis Internet of Things.

Pada era perkembangan teknologi khususnya dibidang pertanian dan perkebunan sudah berkembang teknik penyiraman tanaman yang tepat agar kelembapan tanah tetap terjaga [1][2][3]. Penelitian tentang monitoring kualitas tanah telah dilakukan oleh Jupri [4] yaitu alat untuk mengukur $\mathrm{pH}$, suhu, dan kelembaban pada tanah berbasis mikrokontroler ATMega 328P. Pengukuran kelembaban tanah menggunakan sensor soil mouisture, Pengukuran $\mathrm{pH}$ tanah menggunakan elektroda dan pengukuran suhu tanah menggunakan sensor DS18B20. Mikrokontroler ATMega328P digunakan sebagai pengendali dan pemroses sinyal. Alat ini dilengkapi dengan sistem penyimpan data menggunakan SD Card sehingga mudah untuk pengambilan data hasil pengukuran. Tahapan penelitian meliputi proses perancangan, pembuatan dan pengujian alat. Hasil penelitian menunjukkan bahwa kinerja alat ini mampu mengukur $\mathrm{pH}$, kelembaban dan suhu tanah dengan error berturut-turut sebesar $2,68 \%, 1,53 \%$ dan $0,22 \%$.

Kemudian Alaydrus [5] membuat alat untuk mengukur suhu, kelembapan dan $\mathrm{pH}$ tanah serta memetakan hasil pengukuran tersebut menggunakan sensor SHT11 secara langsung saat aktivitas pengolahan emas berlangsung. Pengukuran dilakukan pada kolam pembuangan limbah pada tiga arah yang berbeda, dan memiliki 6 titik sampel masing-masing berjarak 5 m. Pengukuran pada satu titik dilakukan selama 20-21 jam. Diperoleh nilai suhu untuk semua titik berada pada rentang $25,2-30,3{ }^{\circ} \mathrm{C}$. Sedangkan nilai kelembapan tanah berada pada rentang 63,8-89,9\%. Sedangkan nilai $\mathrm{pH}$ tanah berkisar antara 6,8-8,1. Hasil pemetaan menunjukkan persebaran suhu, kelembapan dan $\mathrm{pH}$ tanah dengan pola yang hampir sama, dimana konsentrasi merkuri berbanding lurus dengan suhu dan $\mathrm{pH}$ tanah serta berbanding terbalik dengan kelembapan tanah.

Penelitian lain dilakukan oleh Gunawan [6] yaitu mengukur kelembapan tanah, suhu, $\mathrm{pH}$ serta penyiraman dan pemupukan cair dilakukan secara otomatis pada tanaman tomat. Pengujian dan penempatan sistem dilakukan di dalam sebuah greenhouse dimana pada beberapa parameter ukur seperti suhu udara dan pH dengan menggunakan mikrokontroler, sensor DHT11, sensor kelembapan tanah, sensor pH dan ESP8266 yang terhubung dengan jaringan internet untuk mengirim informasi hasil pada sebuah smartphone yang sudah dilengkapi dengan aplikasi Blynk.

Penelitian terkait pengiriman data secara wireless juga dilakukan oleh peneliti sebelumnya [7][8][9][10][11]. Belum ada di antara penelitian terkini yang menggunakan platform web server ANTARES untuk penyimpanan dan pertukaran data. Platform ANTARES memudahkan pengguna untuk mengeksplorasi data, seperti menampilkan data pengujian ke aplikasi web ataupun aplikasi mobile android. Sehingga petani dapat mengakses data kondisi data melalui smartphone.

Alat ini dapat mengidentifikasi $\mathrm{pH}$ tanah, kelembaban tanah, dan suhu udara yang cocok untuk tanaman cabai. Nilai ketiga parameter tanah dikirim melalui Arduino Uno/Wemos server (ANTARES). Sehingga data kualitas tanah dari hasil persentase alat pengukur kelembaban tanah dan $\mathrm{pH}$ tanah dapat dengan mudah digunakan untuk ditampilkan pada aplikasi mobile atau web. Diharapkan setelah penerapan teknologi ini, petani kebun dan semua yang berperan dalam sektor pertanian dan perkebunan dapat memaksimalkan potensi yang ada di Kalimantan Timur khususnya di kota Samarinda.

\subsection{Tanaman Cabai}

Tanaman cabai dapat tumbuh dengan baik di dataran tinggi maupun dataran rendah dengan ketinggian antara $1-1.500 \mathrm{mdpl}$. Tanaman cabai dapat tumbuh di dataran kering, namun begitu tanaman akan tumbuh dengan optimal jika ditanam pada lahan yang subur dan kaya akan kandungan unsur hara bertekstur gembur, cukup air serta mengandung banyak humus. Tanaman cabai juga dapat tumbuh dengan baik didaerah yang memiliki curah hujan rendah maupun tinggi dengan suhu berkisar 25 sampai dengan 32 derajat Celsius.

Tanaman cabai umumnya dapat tumbuh dengan baik pada tanah yang memiliki banyak bahan organik, bertekstur gembur, tidak terlalu liat, tidak becek, bebas hama. Tanaman cabai dapat tumbuh dengan optimal pada tanah yang memiliki $\mathrm{pH}$ antara $5,5-6,8$ serta $\mathrm{pH}$ optimum $6,0-6,5$. Tanaman yang ditanam pada tanah yang memiliki kandungan $\mathrm{pH}$ kurang dari 5,5 dapat mengalami keracunan. Tanah yang memiliki tingkat keasaman tinggi atau memiliki $\mathrm{pH}$ rendah kurang dari 5,5 dapat diperbaiki dengan cara pengapuran sehingga 
pH-nya dapat naik hingga mendapatkan $\mathrm{pH}$ yang tepat untuk ditanami tanaman cabai, sedangkan pada kondisi tanah basa yang mengandung $\mathrm{pH}$ tinggi yang menyebabkan pertumbuhan tanaman cabai menjadi terhambat. Tanaman cabai memerlukan kelembaban berkisar 80\% serta sirkulasi udara yang lancar. Curah hujan yang tinggi akan meningkatkan kelembaban di sekitar areal pertanaman. Suhu dan kelembaban yang tinggi juga akan meningkatkan intensitas serangan bakteri dan cendawan.

\subsection{Wemos D1 ESP-12E}

WEMOS D1 ESP-12E adalah sebuah development board seperti Arduino dan dikembangkan khusus untuk Internet of Things [12]. Jenis WEMOS ini memiliki arsitektur 32 bit yang lebih baik dibandingkan Arduino. WEMOS dilengkapi konektivitas WiFi. WEMOS ini dapat diprogram menggunakan Arduino IDE. Gambar dari WEMOS D1 ESP-12E yang dapat kita lihat pada Gambar 1.

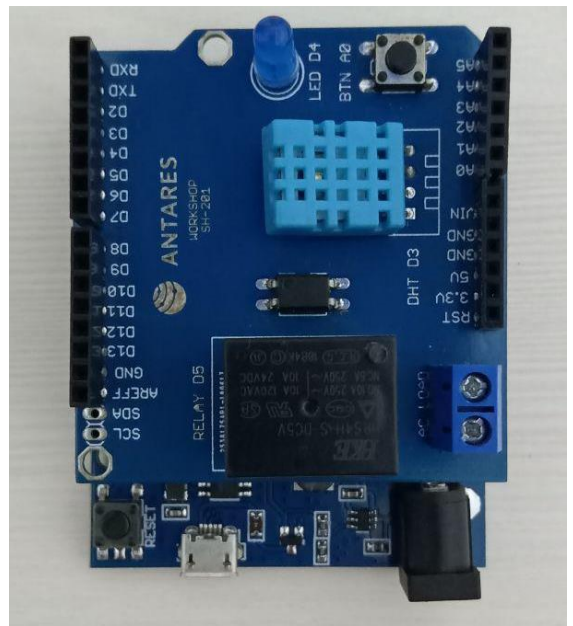

Gambar 1. Wemos D1 ESP-12E

Spesifikasi Wemos D1 ESP-12E yaitu sistem telah on chip dengan push button untuk reset program. Terdapat 16 pin input output dan telah dilengkapi dengan LED, Micro USB, relay, dan memori flash 4MB.

\subsection{ANTARES}

Horizontal IoT Platform yang disediakan oleh ANTARES memudahkan pengembang untuk fokus dalam merancang sistem Internet of Things tanpa perlu merancang database dan web service atau API. Adapun langkah-langkah dalam mengintegrasikan alat yang telah dirancang dengan platform ANTARES ini dapat ditempuh dengan 4 tahap yaitu sebagai berikut.

a. Pendaftaran Akun

Sebelum menggunakan platform ini terlebih dahulu untuk mendaftar dan membuat akun terlebih dahulu. Tampilan pendaftaran dapat dilihat pada Gambar 2 dan Gambar 3. Pengguna dapat mengisikan data diri kemudian pihak ANTARES akan mengirimkan link melalui email untuk verifikasi akun yang baru saja didaftarkan.

\section{ANTARES}

\section{Login}

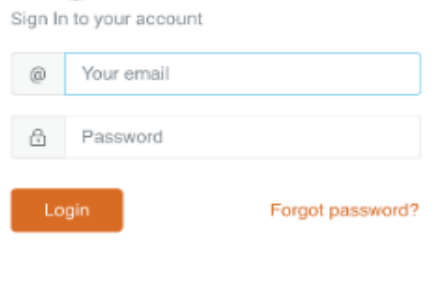

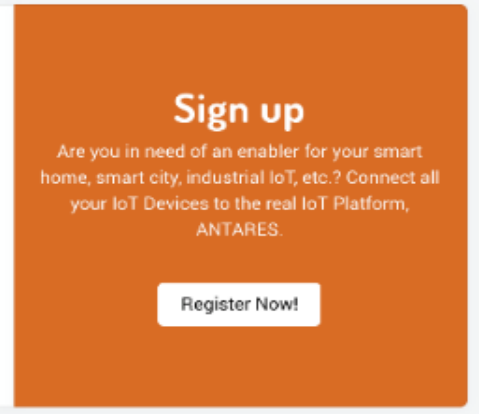

Gambar 2 Halaman Login ANTARES 


\section{ANTARES}

\section{Register}

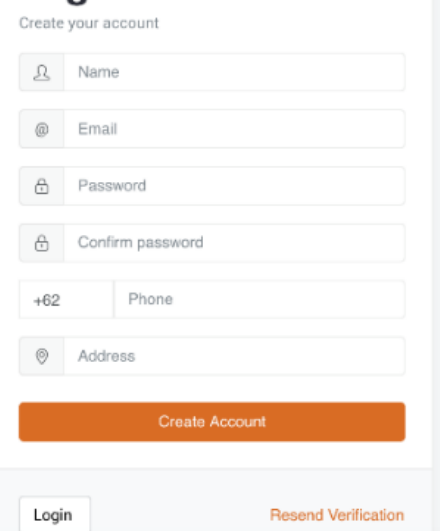

Gambar 3. Halaman Register ANTARES

b. Membuat App

Setelah register dan login, selanjutnya membuat application. Syarat utama sebelum membuat application yaitu harus mengaktifkan access key. Proses ini hanya dilakukan sekali pada pengguna baru ANTARES. Proses pengaktifan access key dapat ditemukan dengan mengunjungi menu Account $\rightarrow$ Access $\rightarrow K e y \rightarrow G e t \rightarrow A c c e s s$ key. Access Key merupakan identitas akun pengguna.

c. Menambahkan Device

Selanjutnya untuk menambahkan suatu device untuk menyimpan data, klik Add Device. Selain klik Add Device untuk menambahkan device, pengguna dapat membuat device dengan menggunakan RESTful API pada segmen HTTP API. Pengguna juga dapat melakukan subscription ke device, jadi jika ada data baru yang masuk ke device, pengguna akan mendapatkan notifikasi. Pengguna dapat memanfaatkan notifikasi tersebut untuk membuat logika pada program.

\section{d. Pengiriman Data ke ANTARES}

Tahap ini merupakan tahap terakhir dalam mengintegrasikan alat dengan platform ANTARES. Di bawah ini adalah contoh kode yang dapat digunakan untuk mengirim data dari proyek ke ANTARES.

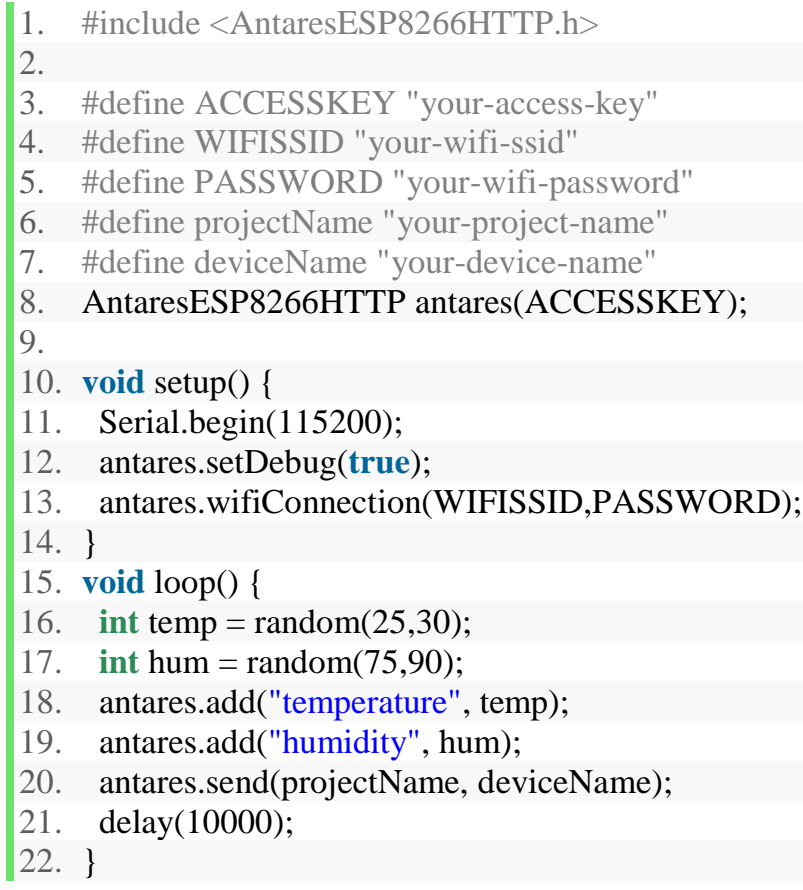




\section{METODE PENELITIAN}

Pada penelitian ini digunakan alat dan bahan berupa Soil Moisture Sensor, Sensor PH tanah, ANTARES Kit / Wemos, Kabel Jumper, Potensiometer, Baterai 9V. Perangkat lunak yang digunakan yaitu sistem operasi Windows 10, android, dan platform web ANTARES. Pembuatan alat hingga pengujian membutuhkan waktu 3 bulan.

\subsection{Perancangan Alat}

Pada penelitian ini dilakukan tahap pembuatan alat pengukur $\mathrm{pH}$ tanah, kelembaban tanah, dan suhu udara berbasis Arduino/wemos yang digambarkan pada diagram blok Gambar 4. Rangkaian perangkat keras disusun dengan sensor $\mathrm{pH}$ tanah, sensor Kelembaban Tanah, dan suhu udara sebagai input. Ketiga sensor akan ditancapkan ke tanah sehingga data akan masuk ke WEMOS dan dikelola menjadi data analog. Data tersebut dikirim ke platform Antares. Pengguna dapat memonitoring data melalui tampilan antarmuka web ANTARES.

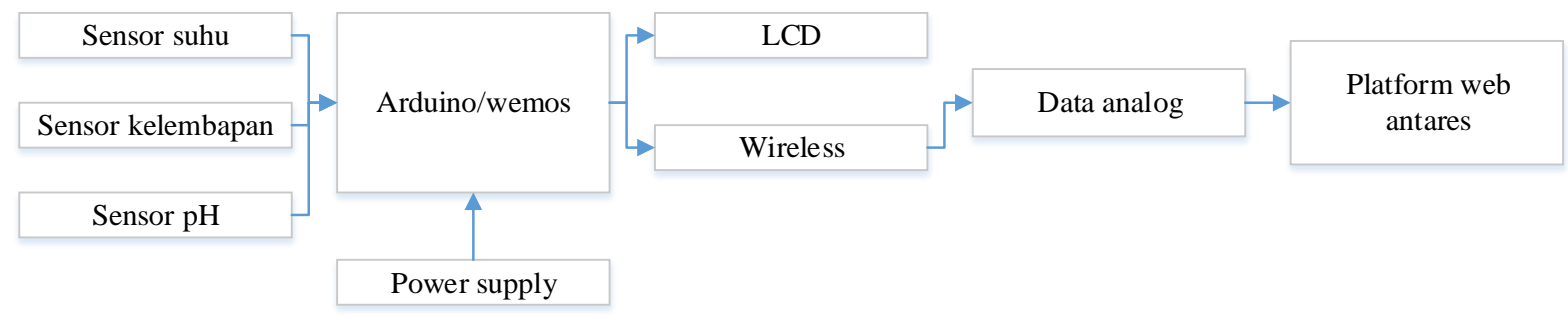

Gambar 4. Diagram Blok Sistem Monitoring

Pada Gambar 5, sketsa alur kerja perangkat keras untuk sistem monitoring suhu, kelembapan dan $\mathrm{pH}$ tanah tanaman cabai. Platform Antares berfungsi sebagai web server data realtime yang dikirim dari sensor kelembapan, sensor $\mathrm{pH}$, dan sensor suhu.

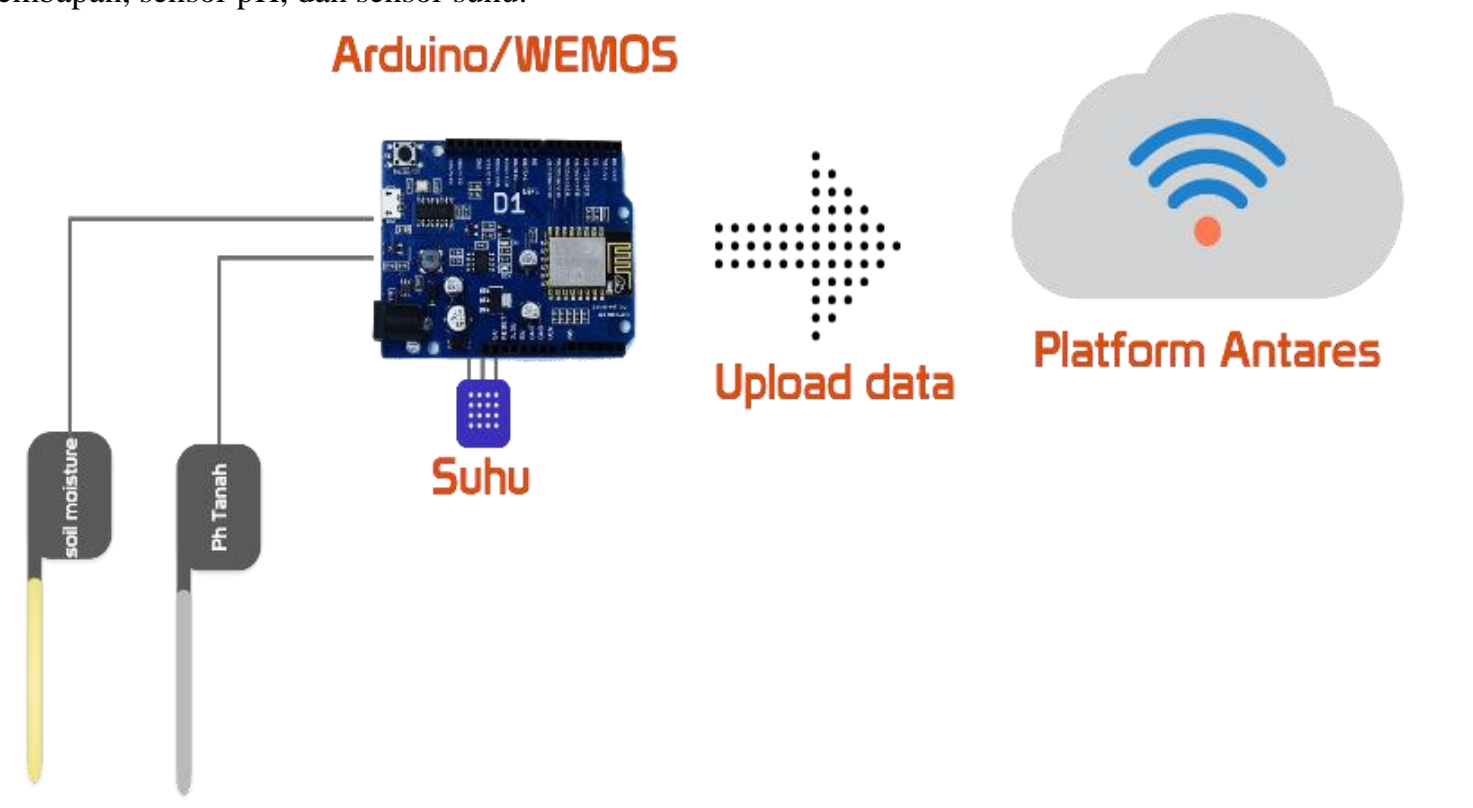

Gambar 5. Sketsa Alur Kerja Perangkat Keras

\subsection{Diagram Alir Penelitian}

Pada penelitian ini dilakukan proses identifikasi masalah pada tanaman cabai. Tiga faktor penentu kondisi tanaman dan panen cabai yaitu suhu, kelembapan dan $\mathrm{pH}$ tanah. Kemudian dilakukan pengumpulan data pendukung untuk selanjutnya dirancang perangkat keras yang sesuai. Setelah rancangan perangkat keras selesai kemudian dilakukan pembuatan software untuk membaca data dari ketiga sensor. Selanjutnya dilakukan pengujian. Jika data suhu, kelembapan dan $\mathrm{pH}$ tanah dapat terlihat di layer LCD dan dapat terkirim ke platform web ANTARES maka alat dapat bekerja dengan baik. Namun, jika tidak dapat terbaca dan terkirim secara realtime, maka dilakukan pengecekan pada perangkat keras. Diagram alir sistem monitoring terdapat pada Gambar 6. 


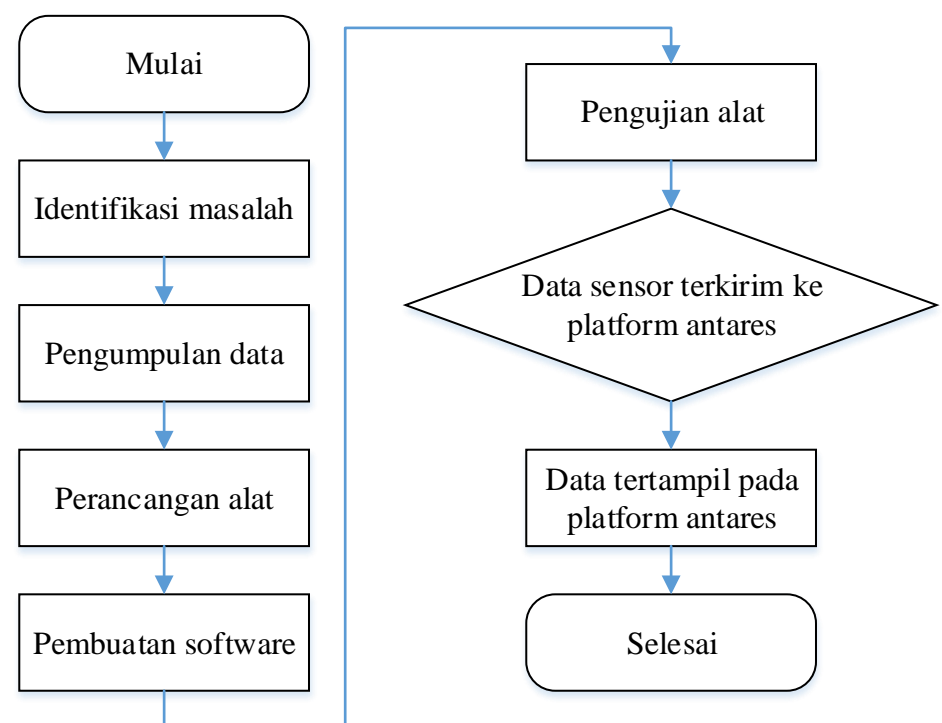

Gambar 6. Diagram Alir Penelitian

\section{HASIL DAN PEMBAHASAN}

Hasil pengukuran $\mathrm{pH}$ tanah, $\mathrm{rH}$ tanah, dan suhu udara pada daerah Samarinda pada bulan Juli 2020. Pada pengujian ini untuk data tanah yang dikirim ke ANTARES seperti pada Tabel 2. Terdapat 6 lokasi yang tepat untuk penanaman pohon cabai yaitu di lokasi 1, 8, 13, 18, 19, 26.

Tabel 1. Hasil Pengujian Alat Pada 30 Lokasi

\begin{tabular}{|c|c|c|c|c|c|}
\hline No & Lokasi & Kecamatan & Suhu & pH & rH \\
\hline 1 & Jl. Anggrek Panda V & Samarinda Ulu & 31,90 & 6 & $80 \%$ \\
\hline 2 & Jl. Polder Air Hitam & Samarinda Ulu & 32,40 & 6,05 & $83 \%$ \\
\hline 3 & Jl. A. Wahab Syahranie & Samarinda Ulu & 31,40 & 6,25 & $75 \%$ \\
\hline 4 & Jl. Bhineka Sempaja & Sungai Pinang & 31,80 & 6 & $70 \%$ \\
\hline 5 & Jl. Damanhuri & Sungai Pinang & 32,40 & 5 & $81 \%$ \\
\hline 6 & Jl. H. A. M. Rifaddin kel tani aman & Loa Janan Ilir & 31,20 & 7 & $79 \%$ \\
\hline 7 & Kota Samarinda Gg. langgar & Samarinda kota & 31,30 & 7,05 & $85 \%$ \\
\hline 8 & Jl. Jakarta Loa Bakung & Sungai Kunjang & 32,20 & 5,15 & $85 \%$ \\
\hline 9 & Jl. Stadion Utama Palaran & Palaran & 31,90 & 6 & $74 \%$ \\
\hline 10 & Jl. Kedondong bukuan & Palaran & 32,90 & 7,05 & $80 \%$ \\
\hline 11 & Jl. Samratulangi Politeknik & Samarinda Seberang & 32,40 & 6 & $97 \%$ \\
\hline 12 & Gertanian Negeri Samarinda & Loa Janan Ilir & 32,90 & 6 & $96 \%$ \\
\hline 13 & Jl. Rapak Indah Gg. Anugrah & Sungai Kunjang & 31,80 & 6 & $81 \%$ \\
\hline 14 & Jl. Daeng mangkona Gg. Citra 4 & Samarinda Seberang & 31,90 & 7 & $82 \%$ \\
\hline 15 & Jl. Lumba-Lumba Selili & Samarinda Ilir & 31,80 & 7 & $75 \%$ \\
\hline 16 & Jl. L amin Indah Dadi Mulya & Samarinda Ulu & 31,20 & 7 & $50 \%$ \\
\hline 17 & Jl. Damai Sidomulyo & Samarinda Ilir & 32,20 & 7,25 & $81 \%$ \\
\hline 18 & Jl. Tri Dharma & Samarinda Utara & 31,90 & 5 & $78 \%$ \\
\hline 19 & Jl. Hidayah Lok Bahu & Sungai Kunjang & 32,40 & 6 & $80 \%$ \\
\hline 20 & Jl. Ringroad Gg. 5 & Samarinda Utara & 32,40 & 7 & $55 \%$ \\
\hline 21 & Jl. Damai Rapak Dalam & Loa Janan Ilir & 31,20 & 6 & $60 \%$ \\
\hline 22 & Jl. Padang Golf Sengkotek & Loa Janan Ilir & 31,40 & 7 & $73 \%$ \\
\hline 23 & Jl. Ampera & Palaran & 31,20 & 6.15 & $70 \%$ \\
\hline 24 & Jl. Mangku Jenang Dalam & Palaran & 32,90 & 7 & $82 \%$ \\
\hline 25 & Jl. Delima & Palaran & 32,80 & 5.25 & $70 \%$ \\
\hline 26 & Jl. Rapak Mahang & Sambutan & 32,60 & 6 & $84 \%$ \\
\hline 27 & Jl. Sultan Sulaiman & Samarinda Ilir & 31,60 & 7.05 & $68 \%$ \\
\hline 28 & Jl. Pelita 4 2 & Samarinda Ulu & 31,40 & 6 & $75 \%$ \\
\hline 29 & Jl. Rumbia 2 Sidomulyo & & & 6 & $75 \%$ \\
\hline 30 & Jl. Kadrie Oening 25 AiR Putih & & $30 \%$ \\
\hline & & & & \\
\hline
\end{tabular}




\subsection{Rangkaian Alat}

Pada Gambar 7 perangkat Arduino/Wemos tersambung ke sensor $\mathrm{pH}$ Tanah, $\mathrm{rH}$ tanah, dan suhu udara dengan penghubung kabel jumper. Potensiometer digunakan untuk mengatur tegangan listrik. Pada Gambar 8 ini merupakan hasil dari data $\mathrm{rH}$ Tanah atau kelembapan tanah dan suhu udara yang disimpan di ANTARES dan data tersebut dapat digunakan oleh aplikasi web dan android. Berdasarkan Gambar 9, data $\mathrm{pH}$ tanah berhasil terbaca melalui platform web Antares. Data dapat diatur untuk dilakukan pengiriman secara berkala.

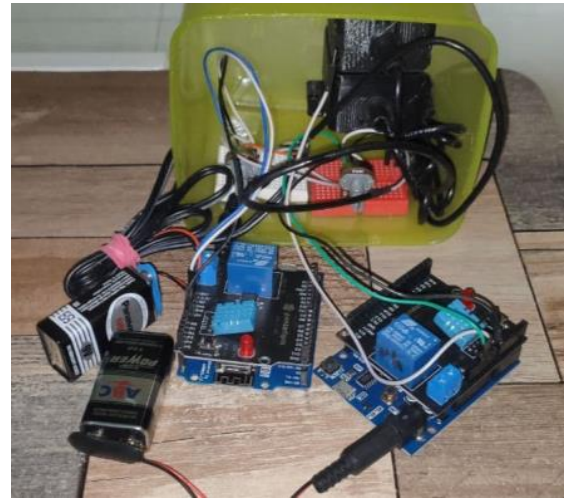

Gambar 7. Rangkaian Sensor pH, rH Tanah, Suhu

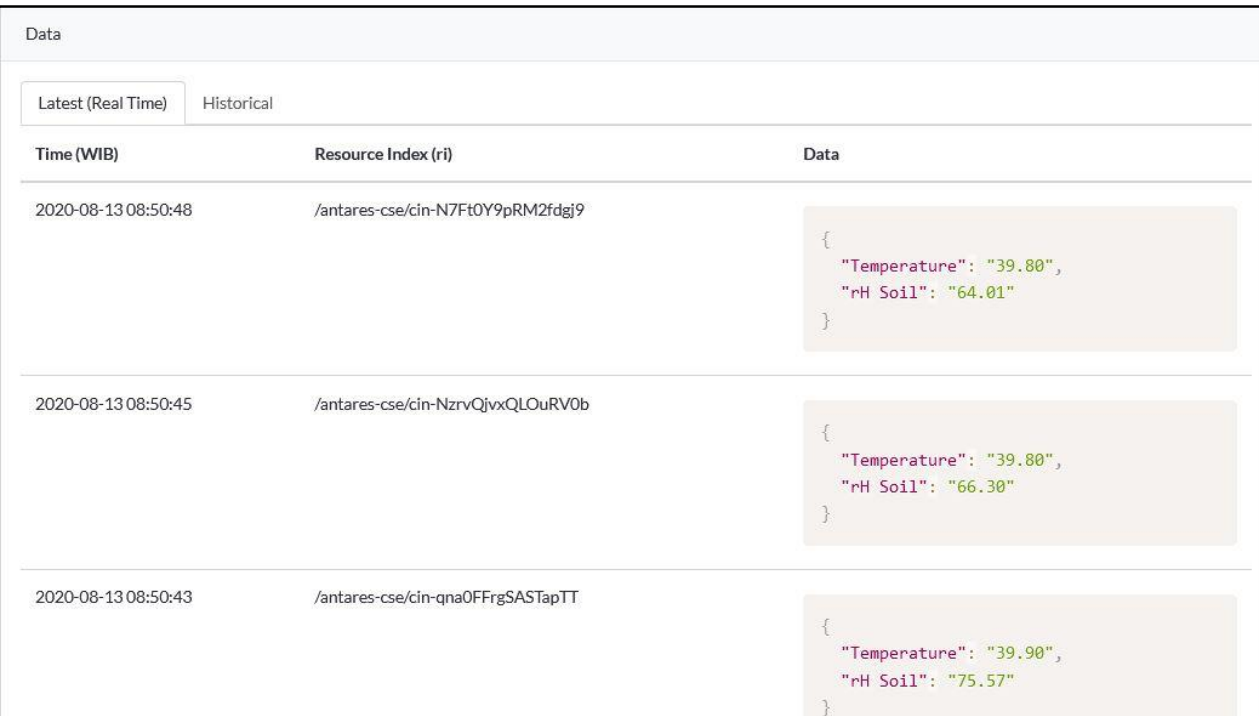

Gambar 8. Hasil Data rH Tanah dan Suhu udara di Antares

\begin{tabular}{|c|c|c|}
\hline Latest (Real Time) & Historical & \\
\hline Time (WIB) & Resource Index (ri) & Data \\
\hline 2020-08-1308:56:41 & /antares-cse/cin-Ui3PqtXvSYuZUQX- & \} "pH Soil": "7.18" \\
\hline 2020-08-1308:56:39 & /antares-cse/cin-X1UlnVlbQEOOEDxt & \{ \\
\hline 2020-08-13 08:56:37 & /antares-cse/cin-wec2fUDcTTmSBuK2 & f \\
\hline
\end{tabular}

Gambar 9. Hasil Data pH Tanah Yang Tersimpan Di Antares 
Pada Gambar 10, dapat dilihat bahwa ketiga data suhu, kelembapan, dan $\mathrm{pH}$ tanah setelah ditarik ke aplikasi web. Aplikasi web ini dibangun dengan framework Laravel. Pada aplikasi web ini, data dari sensor yang tersimpan di ANTARES, ditarik dan ditampilkan secara real time. Kemudian pada bagian ini juga terdapat grafik harian kondisi tanah untuk memantau $\mathrm{pH}$ tanah, kelembaban tanah, suhu udara.

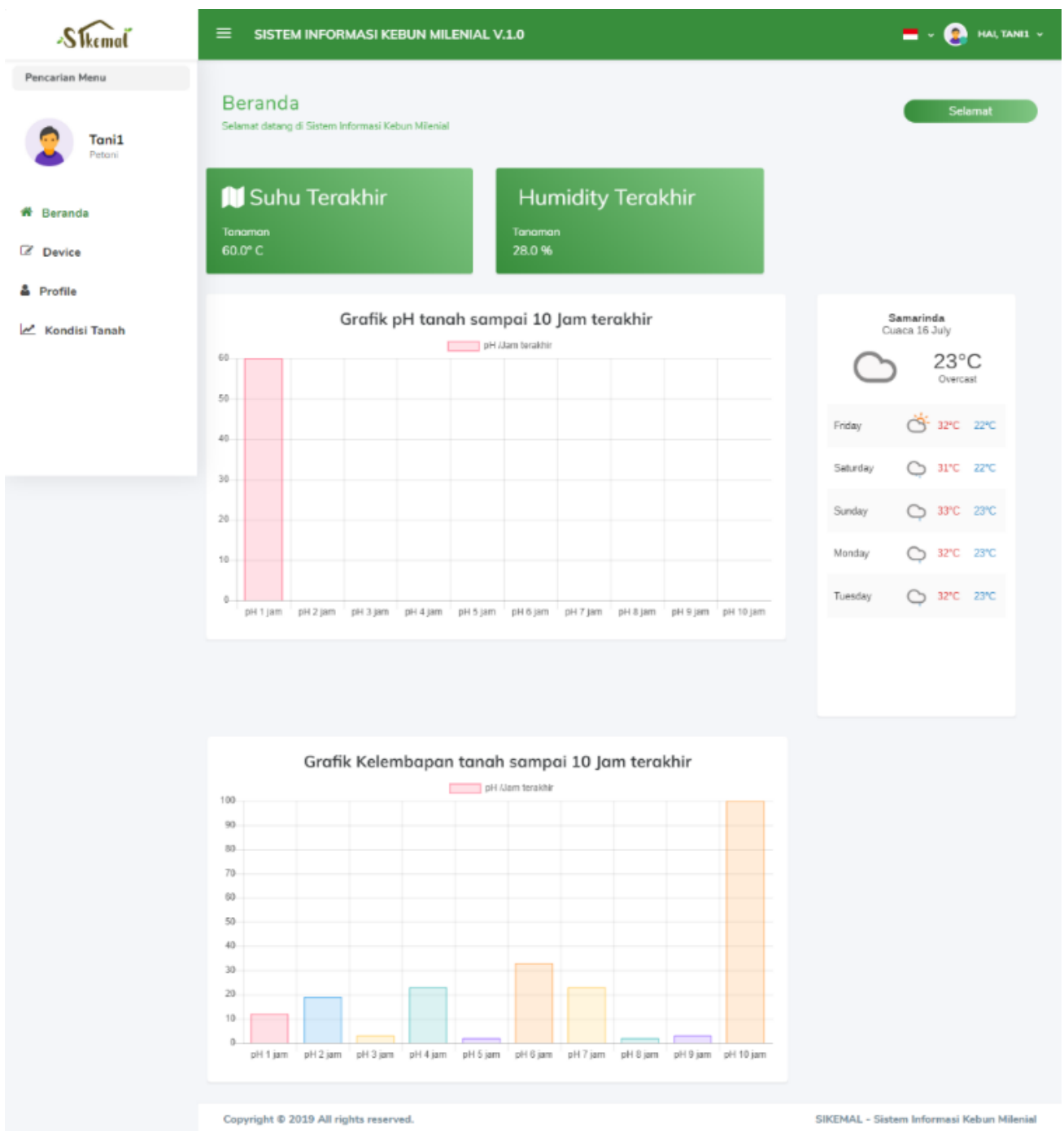

Gambar 10. Tampilan web

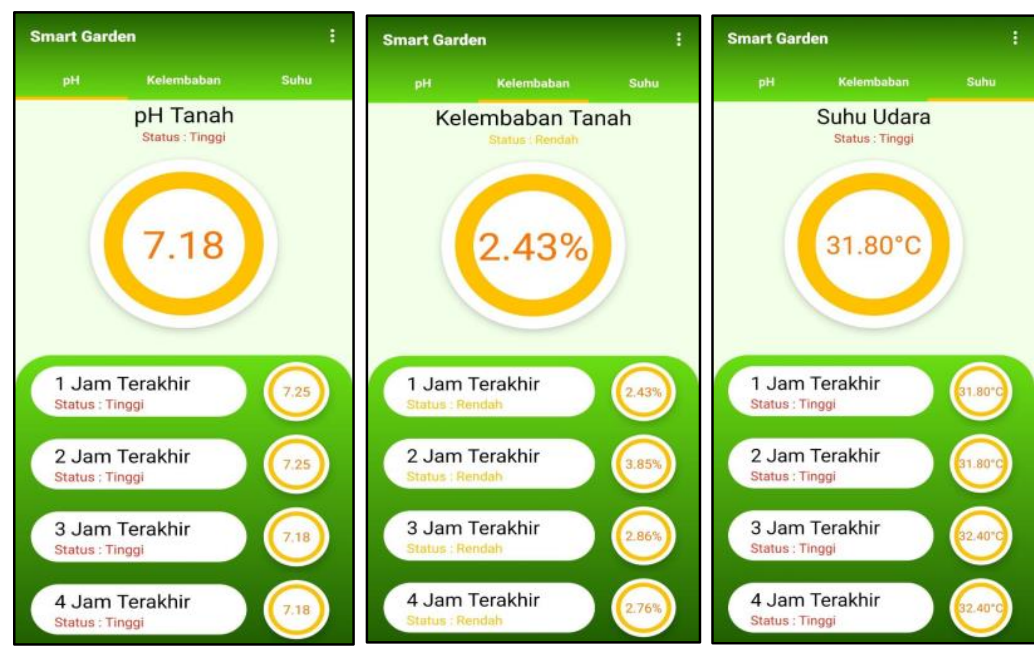

Gambar 11. Tampilan pH pada android 
Setelah itu dilakukan uji coba dengan menarik data dan menampilkan pada aplikasi android seperti pada Gambar 11. Pada aplikasi ini, dapat ditampilkan kondisi pH Tanah, Kelembapan, dan Suhu. Terdapat tampilan menu kondisi tanah parameter $\mathrm{pH}$ yang menampilkan informasi mengenai kondisi tanah saat ini beserta daftar Riwayat kondisi tanah dalam 5 jam terakhir.

\section{KESIMPULAN}

Pembuatan alat ukur pH tanah, kelembapan tanah, dan suhu berbasis Internet of Things berhasil dibuat. Alat ukur ini berhasil mengirimkan data dari sensor yang berupa data analog ke platform ANTARES. Pada penelitian ini juga dibuat aplikasi web dan aplikasi android untuk memudahkan petani dalam memonitoring kondisi tanah. Pengujian alat dilakukan dengan mengambil sample kondisi tanah dari 30 lokasi. Hasil yang diperoleh yaitu alat dapat bekerja dengan baik di 30 lokasi. Berdasarkan uji terhadap 30 lokasi, terdapat 6 lokasi yang cocok untuk penanaman pohon cabai berdasarkan nilai kelembapan tanah, suhu, dan $\mathrm{pH}$. Penggunaan Wemos/Arduino cukup mudah, namun perlu kalibrasi yang baik untuk tiap sensor. Penelitian dapat ditingkatkan dengan menambahkan parameter lain atau mencoba jenis sensor lain untuk mendapatkan data yang lebih akurat.

\section{UCAPAN TERIMA KASIH}

Terima kasih kepada semua pihak yang terlibat pada penelitian ini khususnya kepada Politeknik Pertanian Negeri Samarinda atas program hibah penelitian Smart Farming.

\section{REFERENSI}

[1] D. Sasmoko, "Sistem Monitoring aliran air dan Penyiraman Otomatis Pada Rumah Kaca Berbasis IoT dengan Esp8266 dan Blynk," CIRCUIT: Jurnal Ilmiah Pendidikan Teknik Elektro, vol. 4, no. 1, p. 1, Mar. 2020. DOI: https://doi.org/10.22373/crc.v4i1.6128

[2] R. Sirait and C. Botiwicaksono, "Sistem Kontrol Kelembaban Tanah Pada Tanaman Tomat Menggunakan PID," Techno.Com, vol. 19, no. 3, pp. 262-273, Aug. 2020. DOI: https://doi.org/10.33633/tc.v19i3.3668

[3] N. Azzaky and A. Widiantoro, "Alat Penyiram Tanaman Otomatis Berbasis Arduino Menggunakan Internet Of Things (IOT)," Jurnal Elektronika, Listrik, Telekomunikasi, Komputer, Informatika, Sistem Kontrol (J-Eltrik), vol. 2, no. 2, Jan. 2021. DOI: https://doi.org/10.30649/j-eltrik.v2i2.48

[4] A. Jupri, A. Muid, and - Muliadi, "Rancang Bangun Alat Ukur Suhu, Kelembaban, dan pH pada Tanah Berbasis Mikrokontroler ATMega328P," Jurnal Edukasi dan Penelitian Informatika (JEPIN), vol. 3, no. 2, pp. 76-81, 2017. DOI: https://doi.org/10.26418/jp.v3i2.21210

[5] A. T. Alaydrus, T. Rifandi, L. Mardiana, K. Al Hadi, and S. Minardi, "Rancang Bangun Alat Ukur Monitoring Dan Pengukuran Kontaminasi Tanah (Studi Kasus: Desa Pelangan Kecamatan Sekotong)," Jurnal Sains Teknologi \& Lingkungan, vol. 4, no. 1, pp. 64-72, 2018. DOI: https://doi.org/10.29303/jstl.v4i1.47

[6] R. Gunawan, T. Andhika, . S., and F. Hibatulloh, "Monitoring System for Soil Moisture, Temperature, $\mathrm{pH}$ and Automatic Watering of Tomato Plants Based on Internet of Things," Telekontran: Jurnal Ilmiah Telekomunikasi, Kendali dan Elektronika Terapan, vol. 7, no. 1, pp. 66-78, $2019 . \quad$ DOI: https://doi.org/10.34010/telekontran.v7i1.1640

[7] A. B. Setyawan, M. Hannats, and G. E. Setyawan, "Sistem Monitoring Kelembaban Tanah, Kelembaban Udara, dan Suhu pada Lahan Pertanian Menggunakan Protokol MQTT," Jurnal Pengembangan Teknologi Informasi dan Ilmu Komputer (J-PTIIK) Universitas Brawijaya, vol. 2, no. 12, pp. 7502-7508, 2018. Online

[8] Y. Rahmanto, A. Rifaini, S. Samsugi, and S. D. Riskiono, "Sistem Monitoring pH Air Pada Aquaponik Menggunakan Mikrokontroler Arduino Uno," Jurnal Teknologi dan Sistem Tertanam, vol. 1, no. 1, pp. 23-28, 2020. Online

[9] Y. A. Adnantha and W. A. Kusuma, "Implementasi Wireless Sensor Network Untuk Otomatisasi Suhu Ruang Dan Kelembaban Tanah Pada Greenhouse Berbasis Web Server," Jurnal Online Informatika, vol. 3, no. 1, p. 14, 2018. DOI: https://doi.org/10.15575/join.v3i1.169

[10] V. Y. Muhammad, A. Ma'arif, and S. Sunardi, "Purwarupa Alat Ukur Kandungan pH, Suhu Air dan Suhu Udara pada Pertanian Hidroponik," Jurnal Ilmiah Teknologi Pertanian Agrotechno, vol. 5, no. 2, pp. 81-87, Oct. 2020. DOI: https://doi.org/10.24843/JITPA.2020.v05.i02.p06

[11] H. Nadzif, T. Andrasto, and S. Aprilian, "Sistem Monitoring Kelembaban Tanah dan Kendali Pompa Air Menggunakan Arduino dan Internet," Jurnal Teknik Elektro, vol. 11, no. 1, pp. 26-30, 2019. DOI: https://doi.org/10.15294/jte.v11i1.21383

[12] F. F. Asman, E. Permata, and M. Fatkhurrokhman, "Prototype of Smart Lock Based on Internet Of Things (IOT) With ESP8266," Jurnal Ilmiah Teknik Elektro Komputer dan Informatika, vol. 5, no. 2, pp. 112-119, 2020. DOI: https://doi.org/10.26555/jiteki.v5i2.15317 


\section{BIOGRAFI PENULIS}

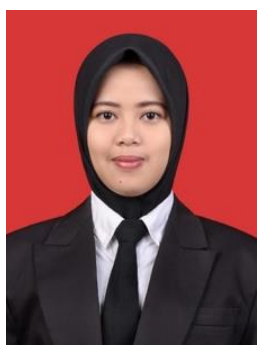

Wahyuni Eka Sari

Memperoleh pendidikan master bidang Teknik Elektro dan Teknologi Informasi di Universitas Gadjah Mada. Fokus penelitian meliputi bidang kecerdasan buatan, pemrograman web dan mobile serta sistem fuzzy. Saat ini beliau merupakan Dosen program studi Teknologi Rekayasa Perangkat Lunak di Politeknik Pertanian Negeri Samarinda dan program studi Teknologi Rekayasa Komputer di Politeknik Negeri Samarinda.

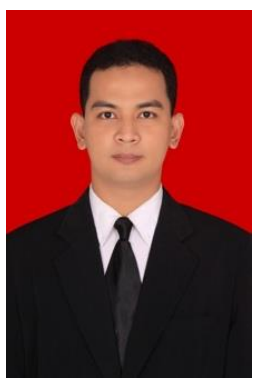

\section{Eko Junirianto}

Lahir di Tarakan tanggal 2 Juni 1989. Menyelesaikan pendidikan S1 Jurusan Ilmu Komputer Fakultas MIPA Unmul berijazah tahun 2012 dan S2 Jurusan Ilmu Komputer \& Elektronika MIPA UGM berijazah tahun 2015. Bidang yang diminati beliau Renewable Energy \& Signal Processing. Saat ini beliau menjabat menjadi Dosen program studi Teknologi Rekayasa Perangkat Lunak di Politeknik Pertanian Negeri Samarinda.

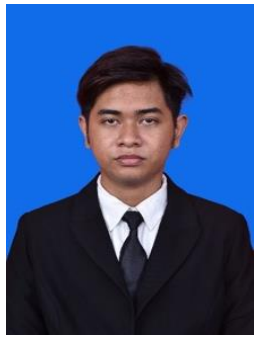

\section{Geofani Fatur Perdana}

Lahir di Balikpapan, pada tanggal 29 November 1997. Penulis adalah mahasiswa Program Studi Teknologi Rekayasa Perangkat Lunak, Jurusan Manajemen Pertanian, Politeknik Pertanian Negeri Samarinda. 